\title{
Impact of ultraviolet radiation on physiology and development of zoospores of the brown alga Alaria esculenta from Spitsbergen
}

\author{
Christian Wiencke $^{a, *}$, Ulrike H. Lüder ${ }^{a}$ and Michael Y. Roleda ${ }^{b,+}$ \\ aSection Seaweed Biology, Alfred Wegener Institute for Polar and Marine Research, Am Handelshafen 12, D-27570 Bremerhaven, Germany \\ biologische Anstalt Helgoland, Foundation Alfred Wegener Institute for Polar and Marine Research, Marine Station, Postfach 180, \\ D-27483 Helgoland, Germany
}

\author{
Correspondence \\ *Corresponding author, \\ e-mail: christian.wiencke@awi.de \\ Received 24 January 2007; revised \\ 7 March 2007
}

doi: 10.1111/j.1399-3054.2007.00923.x

\begin{abstract}
Zoospores of the brown alga Alaria esculenta from Spitsbergen were exposed in the laboratory to photosynthetically active radiation [(P), 400-700 nm], P + UVA radiation ( $\mathrm{PA}, 320-700 \mathrm{~nm}$ ) and $\mathrm{PA}+\mathrm{UVB}$ radiation ( $\mathrm{PAB}, 280-700 \mathrm{~nm})$. Germination rates were determined, and the germination process was documented by light microscopy. In parallel, the presence of UV-absorbing phlorotannins was studied. Photoinhibition and recovery of photosynthesis were monitored as well as DNA damage and repair. After $8 \mathrm{~h}$ of exposure to $P A B$, germination was inhibited. A 16-h exposure to PA and PAB resulted in a dramatic reduction of germination rates. Phlorotannin-containing physodes were observed in the peripheral cytoplasm and physode-like bodies were found outside the spore, still attached to the zoospore as well as freely floating in the medium; this suggested exocytosis. The absorbance of spore suspensions below $300 \mathrm{~nm}$ was higher after $20 \mathrm{~h}$ exposure to P, PA and PAB compared with the dark treatment. About $50 \%$ of the radiation was absorbed by the zoospores, and the rest was absorbed by the medium, especially after PA and PAB exposure. In this way, harmful UV radiation is absorbed before reaching the cells and this is probably the major reason for the relatively low DNA damage after $\leq 8 \mathrm{~h}$ exposure to PAB. Under these conditions, DNA damage was efficiently repaired and there was a notable recovery of photosynthesis. However, after $16 \mathrm{~h}$ exposure to $\mathrm{PA}$ and $\mathrm{PAB}$, the protective and repair mechanisms are surcharged and the zoospores degenerate. The results cast light on the potential impact of enhanced UVB radiation on a dominant component of the seaweed community on Spitsbergen because of stratospheric ozone depletion. The acclimation potential of zoospores of this species to UV radiation as demonstrated here is regarded as conferring a competitive advantage in recruitment over similar species in the upper sublittoral zone.
\end{abstract}

\footnotetext{
Abbreviation - BED, biologically effective doses; PA, photosynthetically active radiation + UVA radiation; PAB, photosynthetically active radiation + UVA + UVB radiation; P, photosynthetically active radiation; UVBR, ultraviolet B radiation; UVR, ultraviolet radiation.
}

${ }^{\dagger}$ Present address: Institute for Polar Ecology, University of Kiel, Wischhofstr. 1-3, Building 12, D-24148 Kiel, Germany 


\section{Introduction}

Since the discovery of stratospheric ozone depletion in Antarctica (Farman et al. 1985), serious concerns have arisen about the impact of enhanced ultraviolet B radiation (UVBR) on the biosphere (Björn et al. 1999). UVBR is absorbed by DNA (Vass 1997) causing formation of cyclobutane-pyrimidine dimers (CPDs), which leads to an inhibition of gene expression and replication (Lois and Buchanan 1994). Additionally, certain amino acids and disulphide bonds between cysteine residues in proteins absorb UVBR, thereby affecting protein folding and functioning (Vass 1997). Peroxidation of unsaturated fatty acids by UVBR-induced oxidative stress affects the structure and function of biological membranes (Murphy 1983).

As a consequence of the numerous molecular effects of UVBR, various physiological processes are impaired. Apart from the effects on the DNA, UVBR mainly targets photosynthesis in seaweeds (Bischof et al. 2006, Franklin and Forster 1997). Conversely, DNA damage can be repaired enzymatically (Pakker et al. 2000, van de Poll et al. 2002). Moreover, the D1 protein of PSII is replaced in a permanent turnover cycle after UVBR-induced damage (Campbell et al. 1998) and oxidative stress is mitigated by antioxidants and enzymatic defence systems (Aguilera et al. 2002, Collen and Pedersen 1996). Damage may also be prevented by UV-absorbing compounds such as mycosporine-like amino acids in red seaweeds (Cockell and Knowland 1999, Karsten et al. 1998, 1999). In brown seaweeds, certain polyphenolic substances, the phlorotannins, were invoked as UVB-protecting compounds (Roleda et al. 2006a, Schoenwaelder 2002). In species with weakly developed repair and protective mechanisms, the organisms respond with reduced growth and/or impaired reproduction (Michler et al. 2002, Roleda et al. 2005, Wiencke et al. 2004a).

As we know today, the unicellular propagation units of seaweeds are the life stages most susceptible to environmental stress (Coelho et al. 2000, Véliz et al. 2006). This has been demonstrated in various, mostly kelp-like, brown algae from the Arctic. In these species, the germination pattern of their zoospores after UVB exposure is closely related to the zonation pattern, as revealed in laboratory and field experiments (Wiencke et al. 2000, 2004a, 2006). Shallow water species, especially Saccorhiza dermatodea and to a lesser extent Alaria esculenta, are most tolerant to ultraviolet radiation (UVR) stress, whereas UVR-susceptible species such as Laminaria digitata and especially Saccharina latissima (syn. Laminaria saccharina) and Laminaria solidungula generally occur at greater depths. Similar results have been obtained in L. digitata, S. latissima and Laminaria hyperborea growing in this sequence from the low tide level down to about $8 \mathrm{~m}$ depth on Helgoland (North Sea; Lüning 1980, Roleda et al. 2005).

Most of the published data about UV effects on brown algal zoospores focus either on the germination pattern or on certain physiological aspects such as the recovery of photosynthesis after UVR exposure (Roleda et al. 2006b) and the protective effect of UV-absorbing compounds (Roleda et al. 2006a). To date, only two studies focussed both on the general development of brown algal zoospores after UVR exposure and on the physiological background. The first of these studies is by Roleda et al. (2005) on Laminariales zoospores from Helgoland. These authors demonstrated that the efficiency of DNA repair, the recovery from PSII damage and the presence of UVabsorbing compounds determine the UVR susceptibility of the studied zoospores and, hence, the germination success. The second of these studies was performed with S. dermatodea from the Arctic (Roleda et al. 2006c). Beside the above-mentioned physiological processes, the process of germination was monitored here by parallel light microscopy.

The present study is focussed on A. esculenta, a species slightly more susceptible to UVR stress compared with $S$. dermatodea. The species occurs in the upper and midsublittoral, whereas $S$. dermatodea grows predominantly in the upper sublittoral (Wiencke et al. 2004b). We have studied UV-induced effects on germination, zoospore structure and development, presence of UV-absorbing compounds, photosynthesis and DNA damage and repair. We will explain the development of the zoospores following UVR exposure as the balance of the various negative effects of UVR on the cell physiology and the protective and repair mechanisms.

\section{Materials and methods}

Fertile sporophytes of $A$. esculenta (L.) Grev. were collected in June 2004 by scuba divers at two locations in Kongsfjorden (Spitsbergen, $78^{\circ} 55^{\prime} \mathrm{N}, 11^{\circ} 56^{\prime} \mathrm{E}$ ). Blades with sori from five different individuals were cleaned of epiphytes, blotted with tissue paper and kept in darkness in a moist chamber at $0^{\circ} \mathrm{C}$ overnight or up to a maximum of 2 days. To induce zoospore release, sori were immersed in $5-10 \mathrm{ml}$ filtered $(0.2 \mu \mathrm{m}$ pore size) seawater at $\pm 15^{\circ} \mathrm{C}$ and exposed to natural sunlight close to a window (Wiencke et al. 2006). The initial zoospore density was estimated using a Neubauer chamber (Brand, Wertheim, Germany). Stock suspensions were diluted with filtered seawater to give spore densities appropriate for each experiment.

For the radiation treatments, two exposure desks were set up with fluorescent tubes $40 \mathrm{~cm}$ (shelf 1) and $30 \mathrm{~cm}$ 
(shelf 2) above the table. Photosynthetically active radiation $(\mathrm{P})$ was provided by two white fluorescent tubes (L65 Watt/25S, Osram, Munich, Germany) and UVR by three UVA-340 fluorescent tubes (Q-Panel, Cleveland, $\mathrm{OH})$, emitting a spectrum similar to solar radiation in the range $295-340 \mathrm{~nm}$. A third desk was set up with only two white fluorescent tubes to study subsequent recovery in $\operatorname{dim}$ white light $\left(8 \pm 2 \mu \mathrm{mol}\right.$ photons $\left.\mathrm{m}^{-2} \mathrm{~s}^{-1}\right)$. To study the effect of different wavelength ranges, the experimental units were covered with three different cut-off filters: Ultraphan transparent (Digefra $\mathrm{GmbH}$, Munich, Germany), Folanorm (Folex $\mathrm{GmbH}$, Dreieich, Germany) or Ultraphan URUV farblos (Digefra $\mathrm{GmbH}$ ) corresponding to the treatments PAB (PA + UVB), PA (P + UVA) and P, respectively. The spectral properties of the foils used are shown by Bischof et al. (2002). Ultraviolet irradiation was determined by use of a Kruse UV-visible spectrometer equipped with a cosine sensor (M. Kruse, Bremerhaven, Germany). The equivalent biologically effective doses (BEDs) were calculated using action spectra for DNA damage (280-320 nm; Setlow 1974) and general plant damage (280-312 nm; Caldwell 1971). P was determined using a cosine quantum sensor attached to a LI-COR data logger (LI-1000, LI-COR Biosciences, Lincoln, NE). Weighted and unweighted irradiances are presented in Table 1.

For determination of germination rates, culture dishes $(53 \times 12 \mathrm{~mm})$ were filled with filtered seawater and two to five drops of zoospore suspension containing approximately $4 \times 10^{5}$ to $5 \times 10^{5}$ spores $\mathrm{ml}^{-1}$ from different sporophytes $(n=5)$ were added to each dish. The dishes were covered with cut-off filters and exposed for 8 and $16 \mathrm{~h}$ to $\mathrm{P}, \mathrm{PA}$ and $\mathrm{PAB}$ under shelf 2 (Table 1 ). After exposure, the spores were transferred to dim white light for 3 or 6 days for recovery. Spores were scored as germinated or not germinated by counting 300 cells per replicate using light microscopes equipped with $20 \times$ seawater immersion objectives. A spore was classified as germinated when at least a germ tube was formed. Dead and living cells were not differentiated.

The germination of zoospores obtained from sporophytes collected on 03 June 2004 was studied after 8 h and $16 \mathrm{~h}$ exposure to $\mathrm{P}, \mathrm{PA}$ and $\mathrm{PAB}$, followed by 2 and 6 days of recovery under dim white light. Suspensions of freshly released zoospores from three individual sporophytes $(\mathrm{n}=3)$ were diluted with filtered seawater to a concentration of $3 \times 10^{5}$ to $4 \times 10^{5}$ spores $\mathrm{ml}^{-1}$. Per sporophyte, 18 culture dishes $(53 \times 12 \mathrm{~mm})$ containing a paper filter at the bottom and a cover slip $(18 \times 18 \mathrm{~mm})$ on the paper filter were prepared and filled each with $10 \mathrm{ml}$ zoospore suspension. The culture dishes were then exposed for 8 or $16 \mathrm{~h}$ to $\mathrm{P}, \mathrm{PA}$ or $\mathrm{PAB}$ under shelf 2 (Table 1) at $7 \pm 1^{\circ} \mathrm{C}$. After exposure, one-third of the samples was analysed immediately, while the rest was transferred for 2 or 6 days to dim white light $(8 \pm 2 \mu \mathrm{mol}$ photons $\mathrm{m}^{-2} \mathrm{~s}^{-1}$ ). At the sampling time, the cover slip with settled spores was removed from the filter, put on a slide, covered with another cover slip $(22 \times 22 \mathrm{~mm})$ and examined in a light microscope (Axioplan imaging, Zeiss, Germany) using a high magnification objective (numerical aperture 1.4). Micrographs were taken with a digital camera (Canon 70, Tokyo, Japan), and images were processed with Adobe Photoshop.

To determine the presence of UV-absorbing compounds, $80 \mathrm{ml}$ zoospore suspension (obtained from sporophytes collected on 25 June 2004) containing $2.5 \times 10^{6}$ spores $\mathrm{ml}^{-1}$, was filled into $85 \times 15 \mathrm{~mm}$ culture dishes and exposed for $20 \mathrm{~h}$ to P, PA and PAB in shelf 2 (Table 1). A portion of the zoospore suspension was kept in the dark (dark control). After exposure, the samples were filled into quartz cuvettes and scanned in the 250-700 nm waveband using UV 2401PC photometer (Shimadzu, Tokyo, Japan) equipped with an integrating sphere. Absorption spectra of the zoospore suspension, zoospores and the medium were determined using (1) zoospore suspension with sea water as reference, (2) zoospore suspension with filtrate as reference and (3) filtrate with seawater as reference, respectively. The filtrate was obtained by filtering the suspension through a $44 \mathrm{~mm}$ diameter $1.0 \mu \mathrm{m}$ pore size Nuclepore ${ }^{\circledR}$ polycarbonate membrane (Whatman, Maidstone, Kent, UK) using a vacuum pump at $400-600 \mathrm{mb}$ to minimize damage to the cells. The experiment was performed three times with spores from different individuals.

Table 1. Experimental irradiances and corresponding biologically weighted irradiances using the biologically effective weighing function for general plant damage (Caldwell 1971) and DNA damage of Escherichia coli (Setlow 1974) in a different exposure desk

\begin{tabular}{|c|c|c|c|c|c|}
\hline & \multicolumn{3}{|c|}{ Experimental irradiance (measured) } & \multicolumn{2}{|c|}{ Weighted irradiance $\left(\mathrm{W} \mathrm{m}^{-2}\right)$ (calculated) } \\
\hline & $\begin{array}{l}\mathrm{P}(400-700 \mathrm{~nm}) \mu \mathrm{mol} \\
\text { photons } \mathrm{m}^{-2} \mathrm{~s}^{-1}\end{array}$ & UV-A $(320-400 \mathrm{~nm}) \mathrm{W} \mathrm{m}^{-2}$ & UV-B $(280-320 \mathrm{~nm}) \mathrm{W} \mathrm{m}^{-2}$ & $\begin{array}{l}\text { General plant damage } \\
\text { (Caldwell 1971) }\end{array}$ & $\begin{array}{l}\text { DNA damage } \\
\text { (Setlow 1974) }\end{array}$ \\
\hline Shelf 1 & 21.8 & 5.65 & 0.47 & $3.51 \times 10^{-2}$ & $1.47 \times 10^{-2}$ \\
\hline Shelf 2 & 29.5 & 7.03 & 0.58 & $4.48 \times 10^{-2}$ & $1.60 \times 10^{-2}$ \\
\hline
\end{tabular}


Photosynthetic efficiency of zoospores obtained from sporophytes collected on 03 June 2004 was measured as variable fluorescence of PSII by use of a water pulse amplitude modulation fluorometer connected to a PC with WINCONTROL software (Heinz Walz GmbH, Effeltrich, Germany). Immediately after adjustment of spore density $\left(4 \times 10^{5}\right.$ to $5 \times 10^{5}$ spores $\mathrm{ml}^{-1}$, not exceeding $1 \mathrm{~h}$ after spore release), the maximum quantum yield $\left(F_{v} / F_{m}\right)$ was measured to determine initial photosynthetic efficiency at time zero $(n=5)$, as described by Hanelt (1998). Cell culture dishes $(35 \times 10 \mathrm{~mm})$ were placed with these controls (volume $5 \mathrm{ml}$ ) and exposed for $48 \mathrm{~h}$ to dim white light. For the treatments, fresh zoospore suspensions $(5 \mathrm{ml})$ were filled into cell culture dishes and exposed for 8 and $16 \mathrm{~h}$ under shelf 1 and 2 to the three radiation treatments (Table $1 ; \mathrm{n}=5$, per treatment) at $7 \pm 1^{\circ} \mathrm{C}$. After exposure, $F_{v} / F_{m}$ was determined and the spore suspensions were exposed for $48 \mathrm{~h}$ to dim white light for recovery. The spores settled and germinated in the meantime were gently resuspended by jetting the medium against the bottom of the culture dish using Eppendorf pipettes, and $F_{v} / F_{m}$ was determined for a second time.

DNA damage and its subsequent repair were determined in zoospores obtained from sporophytes collected on 12 June 2002 after exposure for 1, 4, 8 and $16 \mathrm{~h}$ to PAB under shelf 1 and shelf 2 (Table 1 ). Forty millilitre of the spore suspension $\left(5 \times 10^{5}\right.$ spores $\left.\mathrm{ml}^{-1}\right)$ was used for each experimental unit. For each treatment, six experimental units were prepared. After exposure, three experimental units were processed immediately, while the other three were transferred for 2 days to dim white light for recovery. Settled and germinated spores were resuspended as described above. The spore samples were filtered through $44 \mathrm{~mm}$ diameter $1.0 \mu \mathrm{m}$ pore size Nuclepore ${ }^{\circledR}$ polycarbonate membrane. Filters were then placed separately into $2 \mathrm{ml}$ Eppendorf tubes and frozen at $-80^{\circ} \mathrm{C}$ for further analysis.

For DNA extraction, the filters with the frozen spore samples were incubated in cetyltrimethyl ammonium bromide (CTAB) extraction buffer, as described by van de Poll et al. (2001) and modified by Roleda et al. (2004). After DNA extraction, the pellet obtained was dissolved in $0.2 \mathrm{ml}$ Tris-EDTA buffer ( $10 \mathrm{mM}$ Tris, $1 \mathrm{mM}$ EDTA, $\mathrm{pH}$ 8.0), treated with RNAase (5 $\mu$ l of $10 \mathrm{mg} \mathrm{ml}^{-1}, 30 \mathrm{~min}$, $37^{\circ} \mathrm{C}$; Sigma, St Louis, MO) and stored at $-20^{\circ} \mathrm{C}$. The DNA concentration was quantified fluorometrically using the PicoGreen assay (Molecular Probes, Eugene, OR) and a Cary Eclipse Fluorescence Spectrophotometer (Variance Scientific Instrument, Palo Alto, CA). For calibration, a dilution series with a known amount of DNA (Serva, Heidelberg, Germany) was used.

Content of CPDs was determined using an immunoassay as described by van de Poll et al. (2001). Heat- denatured samples containing 50 ng DNA were transferred to a nitrocellulose membrane (Protran BA 79, pore size $0.1 \mu \mathrm{m}$, Schleicher and Schuell, Keene, NH) with a Minifold I SRC96 dot blot apparatus (Schleicher and Schuell). After a two-step antibody assay, the membrane was treated with ECL Western blotting detection reagent (Amersham, Little Chalfont, Buckinghamshire, UK) and sealed in a transparent plastic folder. Subsequently, the films were exposed to photosensitive ECL films (Amersham) at different exposure times and then developed using X-ray film developer. Developed films were scanned using a Biorad imaging densitometer (Model GS-700, Bio-Rad, Hercules, CA). Quantification of the grey scale values was done by use of Multi-Analyst (BioRad). A calibration series of UV-irradiated calf thymus DNA (Serva) supplemented with unexposed DNA was included giving $1 \mu \mathrm{g} \mathrm{ml}^{-1}$ DNA for each calibration point. The UV-irradiated DNA (45 min exposure to 2 TL-20W/12 lamps, Philips, Eindhoven, the Netherlands) was previously calibrated against UV-irradiated Hela DNA with known amounts of CPDs (kindly provided by A. Vink). CPDs were quantified by comparing the grey scales within the linear range of the film.

Data were tested for homogeneity (Levene Statistics) and normality (Kolmogorov-Smirnov test) of variance. Corresponding transformations were done to heteroskedastic and non-normal data. Response of dependent variables to varying irradiance and exposure time were tested using ANOVA $(P<0.05)$. All analyses were followed by Duncan's multiple range test $(P=0.05)$. Statistical analyses were done using SPSS program (SPSS, Chicago, IL).

\section{Results}

Spore germination was tested in two separate experiments under shelf 2 with materials collected on 03 June 2004 and 25 June 2004 (Fig. 1). Germination rates determined after 8 or $16 \mathrm{~h}$ exposure to $\mathrm{P}$ and 3 days of recovery (control) were significantly similar $(P<0.05)$ and varied between 43.9 and $50.2 \%$ in the two experiments. In the first experiment, germination rates were insignificantly reduced to the same degree after $8 \mathrm{~h}$ exposure both to PA and PAB. In the second experiment, germination was more strongly reduced after $8 \mathrm{~h}$ exposure to $\mathrm{PAB}$ compared with the PA treatment. After $16 \mathrm{~h}$ exposure to $\mathrm{PA}$ and $\mathrm{PAB}$, there was a strong inhibition of germination in both experiments with the strongest effect under the PAB treatment.

After $8 \mathrm{~h}$ exposure to $\mathrm{P}$, the zoospores have already developed short germination tubes (Fig. 2A). At this time, the zoospores contained one elongated, arcuate, yellowbrownish chloroplast (green arrows) and several globular physodes of grey appearance often located at the 
A 3 June 2004, Blomstrandhalvøya
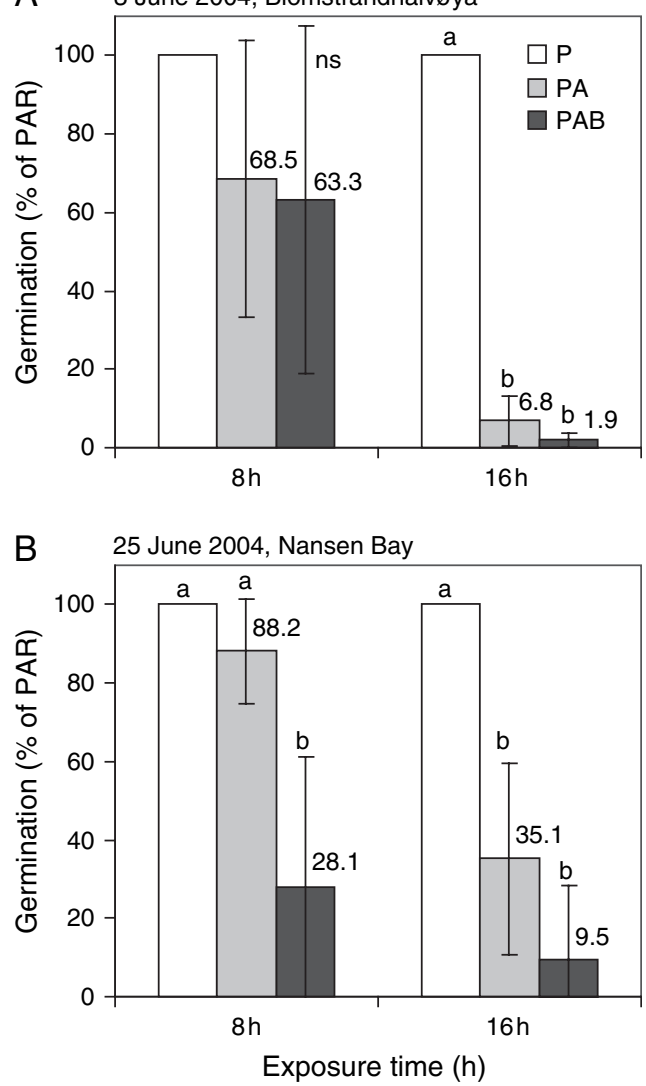

Fig. 1. Spore germination, expressed as percentage of the $P$ treatment, in $A$. esculenta zoospores collected at two sites in Kongsfjorden ( $A$ and $B$ ) after different times of exposure to $P, P A$ and PAB in shelf 2 (Table 1) and after 3 days recovery in dim white light. Means $\pm S D(n=5)$. Data were tested by ANOVA $(P<0.05)$. Letters on graph show the result of Duncan's multiple range test $(P<0.05)$; different letters refer to significant differences between mean values; ns, not significant.

periphery of the cell (black arrows). Furthermore, physode-like bodies were observed in the medium (yellow arrows). After $16 \mathrm{~h}$ exposure to $\mathrm{P}$, the germination tubes were elongated and at first physodes and then chloroplasts started to move into the germination tube (Fig. 2J). On day 2 of recovery, most physodes and chloroplasts were located in the germination tube in both $P$ treatments (Fig. 2D, M), while the embryospores (blue arrows) were almost free of organelles. The physodes appeared larger. On day 6 of recovery, the first cell of the new gametophyte was formed at the end of the germination tube in both $\mathrm{P}$ treatments, resulting in an empty embryospore and an almost empty germination tube (Fig. 2G, P).

After $8 \mathrm{~h}$ exposure to PA, zoospores of $A$. esculenta showed almost no germination tubes. A characteristic feature was the presence of physode-like bodies attached to the plasma membrane of the zoospores in the external medium (red arrows, Fig. 2B). However, after 2 and 6 days of recovery (Fig. 2E, $\mathrm{H}$ ), the further development was similar to that in the $\mathrm{P}$ treatment. After exposure to $16 \mathrm{~h}$ PA, most zoospores still appeared healthy and showed characteristically shaped chloroplasts. The physodes increased in number and were located predominantly at the cell periphery (Fig. 2K). But after 2 days of recovery, severe damage became evident. There was no germination, and most of the zoospores appeared pale and were conspicuously filled with physodes (Fig. 2N). After 6 days of recovery, the cells disintegrated (Fig. 2Q).

After $8 \mathrm{~h}$ exposure to $\mathrm{PAB}$, almost no germination tubes were observed, but physode-like bodies were again observed in the medium (yellow arrows) and attached to the plasma membrane of the zoospore (red arrows, Fig. 2C). On day 2 of recovery, zoospores still appeared healthy and showed characteristic chloroplasts. Physodes seemed to fuse and increased in size. Physode-like bodies were found attached to the zoospores and in the medium (Fig. 2F). On day 6 of recovery, there was still no germination, and most of the zoospores looked pale and cell degeneration started (Fig. 2I). After exposure to $16 \mathrm{~h} \mathrm{PAB,}$ the zoospores appeared pale greenish and the chloroplasts had an irregular shape. The cells contained large physodes, some of which appeared to be released into the medium (Fig. 2L). On day 2 of recovery, the zoospores were pale and there was no evidence for germination (Fig. 2O). After 6 days in dim light, the cells showed autolysis (Fig. 2R). A characteristic feature of the PAB treatment was the formation of numerous large physodes directly after PAB exposure. Large physodes were also present at the two recovery times.

The in vivo absorbance of zoospore suspensions (Fig. 3A), zoospores (Fig. 3B) and the medium (Fig. 3C) was very high in the wavelength range between 350 and $250 \mathrm{~nm}$. The absorption maxima are about three to four times higher compared with the chlorophyll peaks at 440 and $675 \mathrm{~nm}$ in the zoospores (Fig. 3B). The absorbance of the spore suspensions below $300 \mathrm{~nm}$ was higher in all radiation treatments compared with the dark treatment (Fig. 3A). In the spores themselves, an increase in absorbance below $300 \mathrm{~nm}$ was found only in the P treatment, and lower absorbances compared with the dark treatment were determined after exposure to PA and PAB (Fig. 3B). In contrast, absorbances of the media were considerably higher in all three radiation treatments compared with the dark treatment, especially in samples exposed to PA and PAB (Fig. 3C). Further, an absorption peak at $370 \mathrm{~nm}$ was observed in dark control samples.

Photosynthetic efficiency of the freshly released spores (control; $0.432 \pm 0.04$ ) was not significantly different from germinating spores after 2 days recovery (control; 


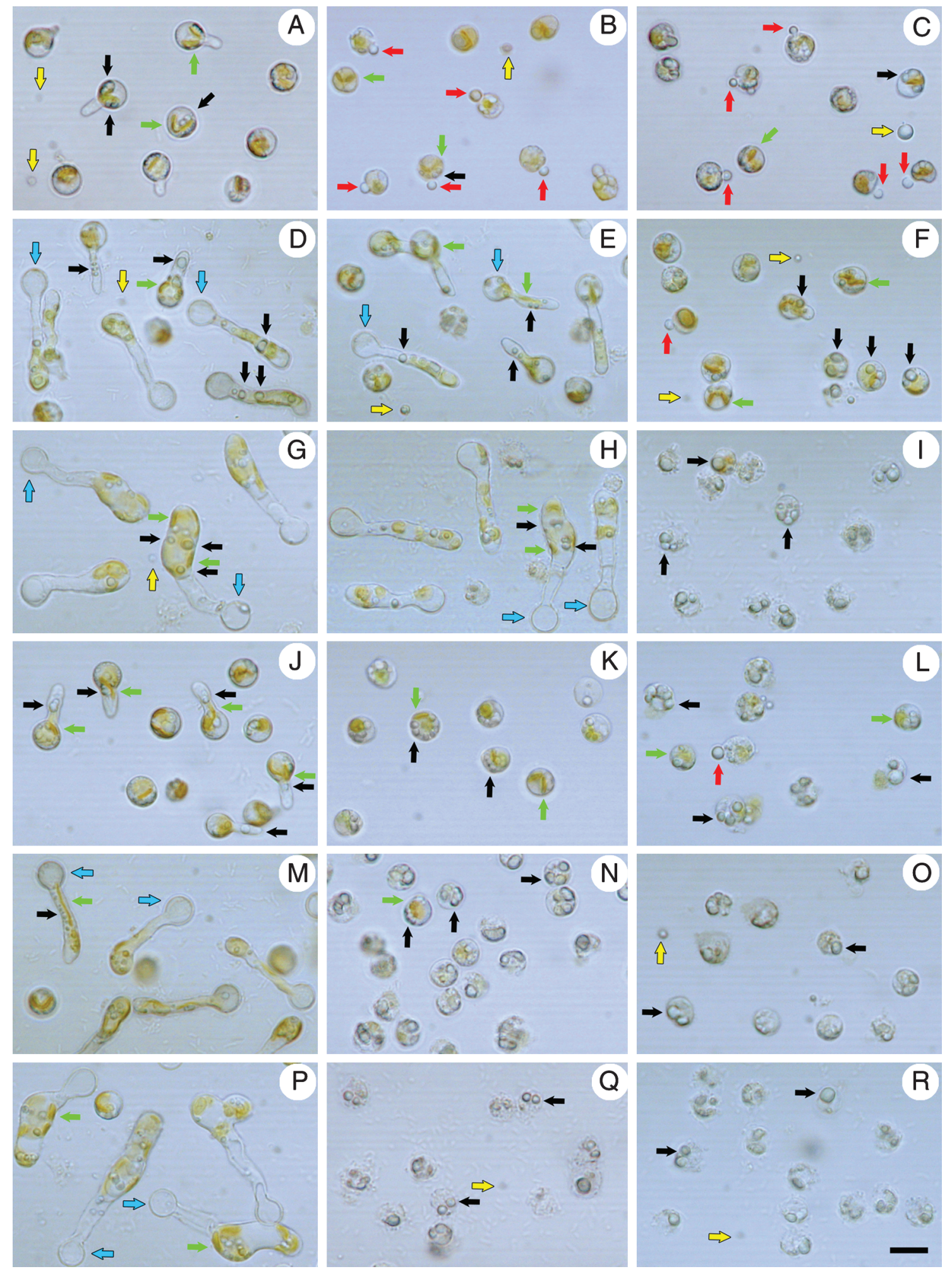

Fig. 2. Light micrographs of zoospores of sporophytes of $A$. esculenta collected on 03 June 2004 after 8 h exposure to $P(A), P A(B)$ and $P A B(C)$ in shelf 2 (Table 1), followed by 2 days $(D, E$ and $F)$ and 6 days recovery in dim white light $(G, H$ and $I)$ and after 16 h exposure to $P(J), P A(K)$ and $P A B(L)$, also followed by 2 days ( $\mathrm{M}, \mathrm{N}$ and $\mathrm{O}$ ) and by 6 days recovery in $\operatorname{dim}$ white light ( $\mathrm{P}, \mathrm{Q}$ and $\mathrm{R})$. Black arrows, physodes; yellow arrows, physode-like vesicle in the medium; red arrows, physodes during extrusion into the medium; green arrows, chloroplasts; blue arrows, empty embryospores. Scale bar: $5 \mu \mathrm{m}$. 

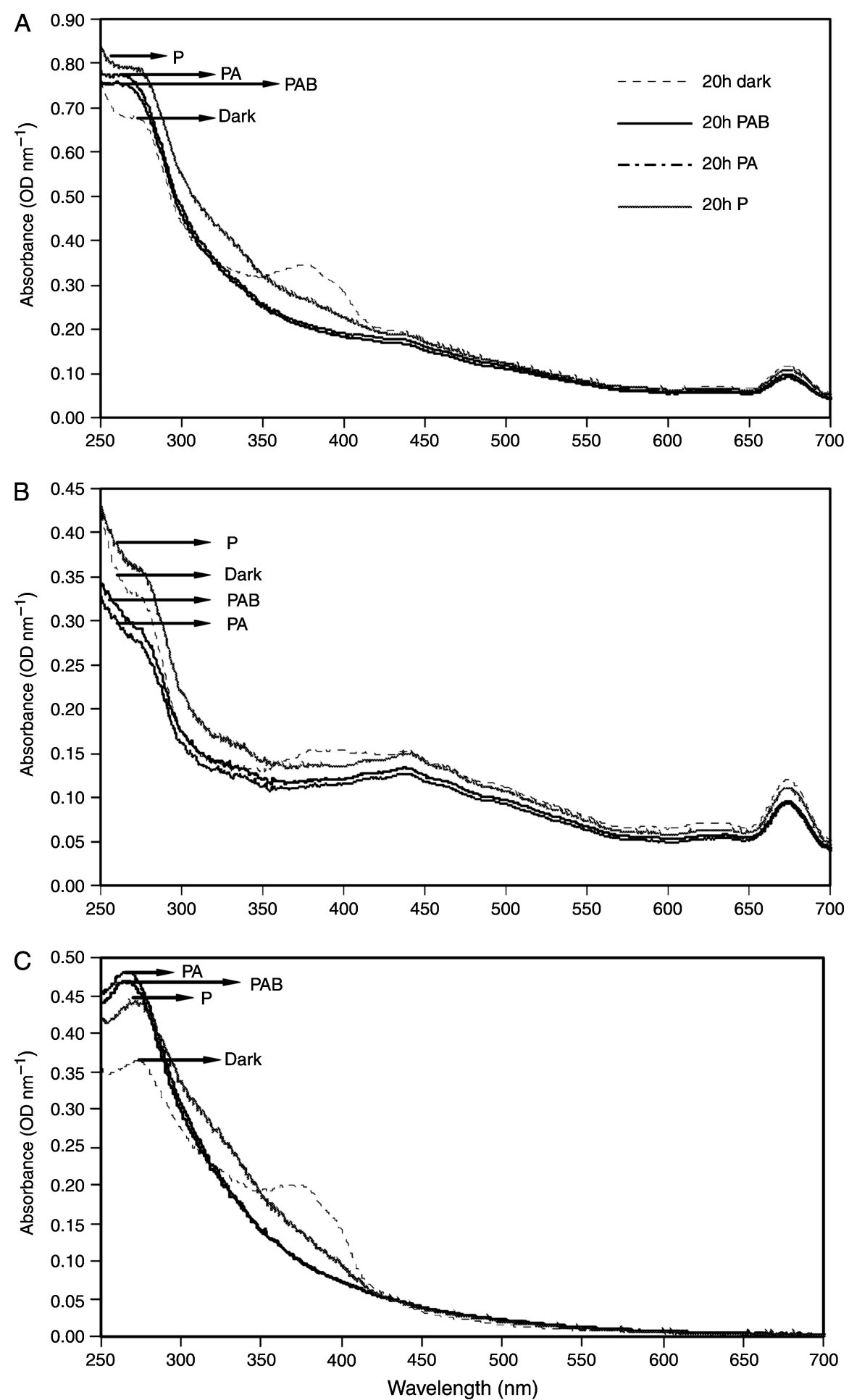

Fig. 3. Absorption spectra of (A) zoospore suspensions, (B) zoospores and (C) the surrounding medium after exposure to $20 \mathrm{~h}$ of $P, P A$ and $P A B$ in shelf 2 (Table 1). Zoospore density was $2.5 \times 10^{6}$ spores $\mathrm{ml}^{-1}$. The results were obtained from spores obtained from three sporophytes collected on 25 June 2004. Experiments were performed in triplicate, but only one experiment is shown here for clarity. 
A Treatment

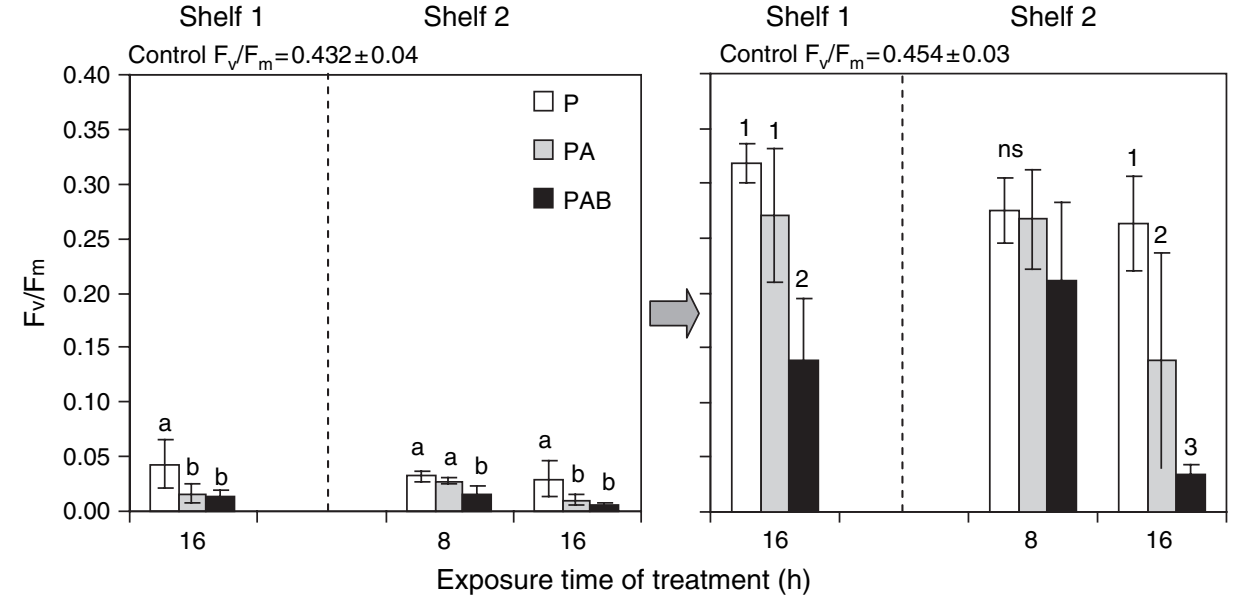

Fig. 4. Photosynthetic efficiency $\left(F_{v} / F_{m}\right)$ of $A$. esculenta zoospores obtained from sporophytes collected on 03 June 2004 (A) after exposure to $P$, PA and $P A B$ in shelf 1 and shelf 2 (Table 1 ) and (B) after 2 days recovery in dim white light. Means $\pm S D(n=5)$. Controls are values after release and 2 days of culture at the same dim white-light condition of the treated samples. Data were tested by ANova $(P<0.05)$. Letters (after exposure) and numbers (after recovery) on graph show result of Duncan's multiple range test $(P<0.05)$; different notations refer to significant differences between mean values; ns, not significant.

$\left.\mathrm{F}_{\mathrm{v}} / \mathrm{F}_{\mathrm{m}}=0.454 \pm 0.03\right)$ in dim white light. Photosynthetic efficiency $\left(F_{v} / F_{m}\right)$ of freshly released spores was considerably inhibited to more than $90 \%$ of the initial value, especially after exposure to PA and PAB (Fig. 4A). Photosynthetic efficiency recovered to about $65 \%$ of the control value in the $\mathrm{P}$ and PA treatment, except in $16 \mathrm{~h}$ exposure to PA under shelf 2, where only about $30 \%$ of the control value was determined. Similarly, recovery of photosynthetic efficiency under the PAB treatment was low and attained values of about 50 to only $8 \%$ of the control.

DNA damage as indicated by formation of CPDs increased significantly $(P<0.05)$ with increasing UVB doses under both irradiance levels (Fig. 5). However, after $16 \mathrm{~h}$ exposure to $\mathrm{PAB}, \mathrm{CPD}$ accumulation was much lower under the lower irradiance of shelf 1 compared with shelf 2, although the calculated BEDs $\left(8.48 \times 10^{2} \mathrm{~J} \mathrm{~m}^{-2}\right.$ and $9.20 \times 10^{2} \mathrm{~J} \mathrm{~m}^{-2}$ ) were in the same range under both irradiances. After recovery in dim white light, there was a relatively efficient repair of the UVB-induced damage in most cases. About $70 \%$ of the induced damage was repaired after exposure to the highest UVB dose $(9.20 \times$ $10^{2} \mathrm{~J} \mathrm{~m}^{-2}$ ).

\section{Discussion}

The presented data give important new insights into the various negative effects of UVR on the zoospores of the studied species and especially on the involved protective and repair mechanisms. We made important observations suggesting exocytosis of phlorotannin-containing physodes in brown algal zoospores. We hypothesise that this process is related to the UV-absorbing capacity of the surrounding seawater, as demonstrated by parallel spectrophotometric measurements. We argue that in combination with an efficient DNA repair, this strategy is the reason for the relatively low DNA damage and the notable recovery of photosynthesis after moderate UVBR exposure. However, prolonged UVBR exposure still resulted in a strong decrease of germination rates.

The strong absorption of zoospore suspensions, of the zoospores themselves and of the surrounding medium at wavelengths below $320 \mathrm{~nm}$ is characteristic for phlorotannins. Isolated phlorotannins of Fucus gardneri absorb strongly in this region with a peak at $265 \mathrm{~nm}$ (Henry and van Alstyne 2004). The monomer of phlorotannins, phloroglucinol, likewise absorbs optimally at this wavelength (Roleda et al. 2006a). The phlorotannins are localised in the cells in small membrane-bound vesicles, the so-called physodes, and are additionally a major component of brown algal cell walls (Schoenwaelder and Clayton 1999). Beside their strengthening role as a cell wall constituent, they are able to chelate calcium (Döpfner et al. 1990) and heavy metal ions, thereby cleansing the cytoplasm of these toxic compounds (Ragan and Glombitza 1986). Moreover, they play an important role in the attachment of spores and zygotes, fertilisation (Schoenwaelder and Clayton 1998) and wound healing (Lüder and Clayton 2002) and as chemical defence against herbivores (Amsler and Fairhead 2006, Schoenwaelder 2002). 


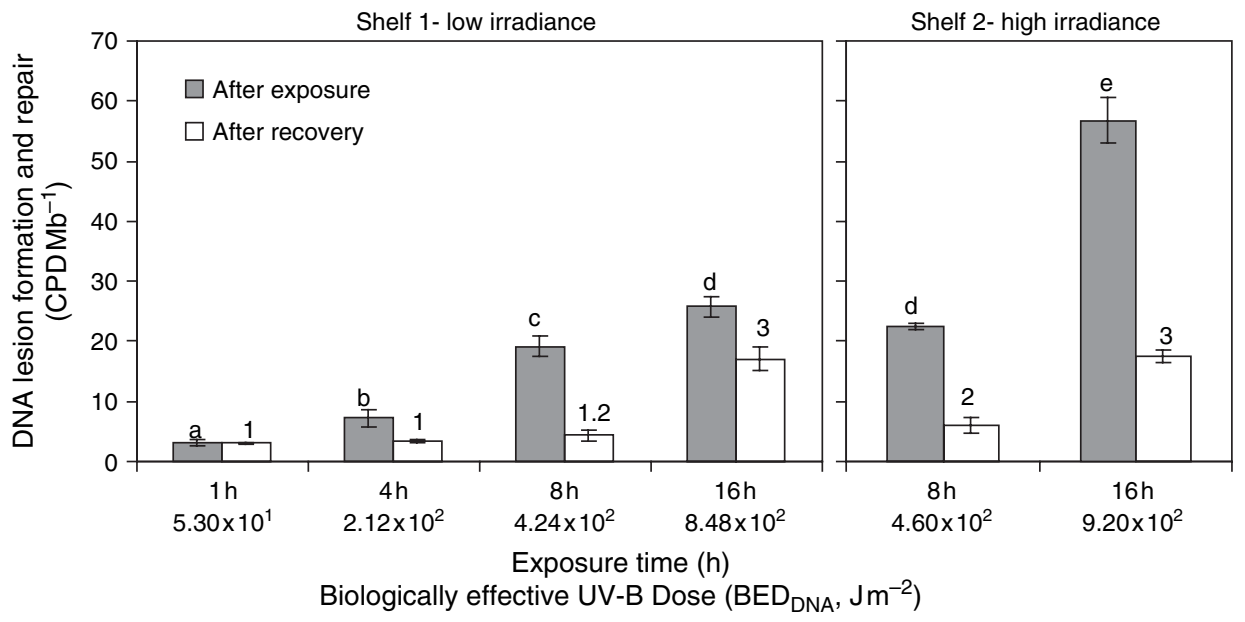

Fig. 5. UVBR-induced DNA damage (CPDs formation per million nucleotides) in zoospores obtained from A. esculenta collected on 12 June 2004 after increasing time of exposure to two irradiances of PAB in shelf 1 and 2 (Table 1) and corresponding DNA damage repair after 2 days recovery in dim white

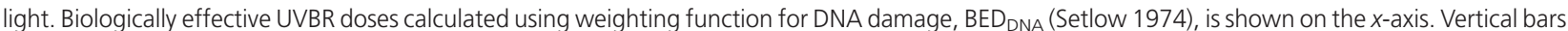
are SD $(n=3)$. Data were tested by ANOvA $(P<0.05)$. Letters (after exposure) and numbers (after recovery) on graphs show result of Duncan's multiple range test $(P<0.05)$; different notations refer to significant differences between mean values.

The function of phlorotannins as UV-protecting compounds came into discussion again after the discovery that phlorotannins can be induced by UVR exposure in thalli of Ascophyllum nodosum (Pavia and Brock 2000, Pavia et al. 1997) and blades of Macrocystis integrifolia (Swanson and Druehl 2002). Similarly, an increase in UVR absorption has been demonstrated in suspensions of zoospores of $S$. dermatodea and $A$. esculenta after UVR exposure (Roleda et al. 2006a). It is probable that the number and size of the physodes increased during the experiment as demonstrated here, in particular not only after 8 and 16 h PAB exposure but also after 16 h PA exposure (Fig. 2). Suspensions of zoospores from the above species are able to protect zoospore cultures from the negative effects of UVR. Similarly, zoospore cultures can be shielded from UVR by solutions of phloroglucinol (Roleda et al. 2006a).

An exudation of phlorotannins after UVBR exposure was first detected by Swanson and Druehl (2002) in M. integrifolia thalli. For the first time, our microscopic data suggest phlorotannin release through exocytosis in zoospores after their exposure to PA or PAB. Physodes were detected in the peripheral cytoplasm of the zoospores, and physode-like bodies were detected while still attached to the zoospores as well as freely floating in the medium (Fig. 2A, B, C). Similarly, in eggs of the brown alga Durvillaea potatorum (Durvillaeales), physodes are located at the periphery of the cell just behind the plasma membrane undergoing exocytosis. The contents of the physodes are discharged as phenolic bodies into the surrounding seawater (Clayton and Ashburner 1994). We hypothesise that observations made here on A. esculenta zoospores similarly indicate a secretion of phenolic bodies into the outside medium through exocytosis.

Compared with zoospores kept in darkness, the absorbance in the UVB region of the spectrum was higher in the surrounding medium after exposure to $\mathrm{P}$, PA or PAB (Fig. 3). Similar results were obtained in S. dermatodea, although secretion of phenolic bodies through exocytosis could not be demonstrated by light microscopy (Roleda et al. 2006c). The release of phlorotannins into the external medium is regarded as a process that strongly enhances the protective capacity of phlorotannins. Physodes are unevenly distributed in the cells and offer only very localised protection against UVR. Certainly, each zoospore may protect each other against UVR in zoospore clouds, but the best protection is obtained if the phlorotannins are released into the surrounding seawater absorbing the harmful UVR before it reaches the cells. After $16 \mathrm{~h}$ exposure to $\mathrm{PAB}$, extrusion of physodes is obviously reduced (Fig. 2L) compared with the $8 \mathrm{~h}$ exposure (Fig. 2C). As phlorotannins in the medium may also suffer photodegradation (Swanson and Druehl 2002), UVR can penetrate the seawater under such conditions and is able to reach the cells and the various cellular targets.

One target of UVR is photosynthesis. Exposure to UVR leads to a reduction in photosynthetic efficiency through an impairment of the reaction centres of PSII (Franklin et al. 2003, Grzymski et al. 2001). In our experiments, exposure to UVR has significantly increased the degree of photoinhibition, but the most pronounced effect of 
additional UVBR exposure is the decrease in the recovery rate during postculture in dim light (Fig. 4). This is known from several other studies on macrothalli of $A$. esculenta (Bischof et al. 1999) and other brown algae (Hanelt et al. 1997). So, the low photosynthetic efficiency at the end of the recovery period in the most strongly UVR-exposed spores indicates photodamage of PSII and may be one reason for the withering and the subsequent cell death. In contrast, the reduction in photosynthetic efficiency in the $P$ treatment is only the result of harmless dissipation of excessively absorbed energy as heat, a protective strategy to avoid photodamage (Hanelt 1996).

The major target for UVR is probably the nucleus (Huovinen et al. 2000). This becomes obvious by the high degree of DNA damage, especially after $16 \mathrm{~h}$ exposure to PAB under shelf 2 (Fig. 5). On the other hand, there is still a relatively high capacity for DNA repair during the recovery period in dim light. This repair is mediated predominantly by blue-light-dependent photolyases but also by light-independent nucleotide excision repair (Pakker et al. 2000). DNA repair has been demonstrated also in spores of other Laminariales (Roleda et al. 2005), spores of S. dermatodea (Roleda et al. 2006c) and in spores of two red algal species (Roleda et al. 2004) as well as in macrothalli of numerous red and brown algae (van de Poll et al. 2001, 2002).

DNA damage is higher in A. esculenta, when comparing DNA damage in A. esculenta (this study) and S. dermatodea (Roleda et al. 2006c) after exposure to the same PAB regime. Under the strongest UVB dose, about 57 CPDs were detected $\mathrm{Mb}^{-1}$, whereas only 33 CPDs $\mathrm{Mb}^{-1}$ were formed in $S$. dermatodea. Moreover, the repair of DNA lesions is more efficient in $S$. dermatodea. In $A$. esculenta, at the end of the recovery period, DNA damage is still apparent after exposure to biologically effective UVB doses $\leq 2.12 \times 10^{2} \mathrm{~J} \mathrm{~m}^{-2}$, whereas no CPDs were detected in $S$. dermatodea after the same treatment.

This result supports the view that the zonation pattern of kelps and kelp-like brown algae is determined by the susceptibility of the zoospores to UVR (Wiencke et al. $2000,2004 a)$. The UV susceptibility of the zoospores is in turn determined by the protective potential against UVR and the activity of the repair mechanisms. Depending on the activity of the protective and repair mechanisms, germination will be inhibited or not be inhibited. The different UV susceptibility of germination of zoospores obtained from sporophytes collected on different dates and at different sites as shown here may be because of a different degree of maturity or a different UV exposure at the collecting site. We must also note that the germination pattern observed here differs somehow from published data, whereas a comparable germination pattern of zoospores of the same species was obtained by Wiencke et al. (2000). In contrast, Wiencke et al. (2004a) could not demonstrate an inhibition of germination after $8 \mathrm{~h}$ exposure to $\mathrm{PAB}$ and after 3 days postculture. A strong inhibition was detected only after $16 \mathrm{~h}$ exposure, but in contrast to the results obtained here only after exposure to $\mathrm{PAB}$ and not under the PA condition. These differences are probably related to different collection times. Whereas Wiencke et al. (2004a) collected the material in August, the zoospores studied here and by Wiencke et al. (2000) were obtained from sporophytes collected in June, during and a short time after sea-ice breakup. Such algal material has been exposed for several months to darkness or dim light and is probably strongly acclimated to these conditions devoid of UVR. In contrast, material collected in August is well acclimated to high irradiance including UVR (Bischof et al. 2002, Hanelt et al. 2001). Similar differences in the germination pattern were also observed in S. dermatodea collected in autumn (Wiencke et al. 2004a) and spring (Roleda et al. 2006c).

Overall, the results of this study give important new insights into the UV susceptibility of zoospores from a dominant component of the seaweed community of Arctic Spitsbergen (Svendsen 1959, Wiencke et al. 2004b). The presented physiological and developmental data help to relate the effect of atmospheric changes, in this case enhanced UVBR through stratospheric ozone depletion, to the performance of the studied species in the sea. Another important aspect is the interaction of the changing radiation condition with the increase of the water temperatures as a result of the greenhouse effect. The subject of the algal responses to these changes is an important future research area.

Acknowledgements - Thanks go to the scuba divers, in particular to Max Schwanitz, Claudia Daniel and Ansgar Gruber, for collecting fertile specimen. Moreover, we thank the International Arctic Environmental Research and Monitoring Facility at Ny Ålesund, Svalbard, for support. We are grateful to Dr Richard Crawford for checking the English.

\section{References}

Aguilera J, Dummermuth A, Karsten U, Wiencke C (2002) Enzymatic defenses against photooxidative stress induced by ultraviolet radiation in Arctic marine macroalgae. Mar Biol 140: 1097-1106

Amsler CD, Fairhead VA (2006) Defensive and sensory chemical ecology of brown algae. Adv Bot Res 43: $1-91$ 
Bischof K, Hanelt D, Wiencke C (1999) Acclimation of maximal quantum yield of photosynthesis in the brown alga Alaria esculenta under high light and UV radiation. Plant Biol 1: 435-444

Bischof K, Kräbs G, Wiencke C, Hanelt D (2002) Solar ultraviolet radiation affects the activity of ribulose-1,5-bisphosphate carboxylase-oxygenase and the composition of photosynthetic and xanthophyll cycle pigments in the intertidal green alga Ulva lactuca L. Planta 215: 502-509

Bischof K, Gómez I, Molis M, Hanelt D, Karsten U, Lüder U, Roleda MY, Zacher K, Wiencke C (2006) Ultraviolet radiation shapes seaweed communities. Rev Environ Sci Biotechnol 5: 141-166

Björn LO, Callaghan TV, Gehrke C, Johanson U, Sonesson M (1999) Ozone depletion, ultraviolet radiation and plant life. Chemosphere: Global Change Sci 1: 449-454

Caldwell MM (1971) Solar UV radiation and the growth and development of higher plants. In: Giese AC (ed) Photophysiology, Vol. 6. Academic Press, New York, pp 131-177

Campbell D, Eriksson MJ, Öquist G, Gustafsson P, Clarke AK (1998) The cyanobacterium Synechococcus resists UV-B by exchanging photosystem II reaction-center D1 proteins. Proc Natl Acad Sci USA 95: 364-369

Clayton MN, Ashburner CM (1994) Secretion of phenolic bodies following fertilization in Durvillaea potatorum (Durvillaeales, Phaeophyta). Eur J Phycol 29: 1-9

Cockell CS, Knowland J (1999) Ultraviolet radiation screening compounds. Biol Rev 74: 311-345

Coelho SM, Rijstenbil JW, Brown MT (2000) Impacts of anthropogenic stresses on the early developmental stages of seaweeds. J Aquat Ecosyst Stress Recov 7: 317-333

Collen J, Pedersen M (1996) Production, scavenging and toxicity of hydrogen peroxide in the green seaweed Ulva rigida. Eur J Phycol 31: 265-271

Döpfner M, Wiencke C, Kirst GO (1990) Calcium compartmentation in Antarctic brown algae.

Ultramicroscopy 32: 7-11

Farman JC, Gardiner BG, Shanklin JD (1985) Large losses of total ozone in Antarctica reveal seasonal $\mathrm{ClO}_{x} / \mathrm{NO}_{x}$ interaction. Nature 315: 207-210

Franklin LA, Forster RM (1997) The changing irradiance environment: consequences for marine macrophyte physiology, productivity and ecology. Eur J Phycol 32: 207-232

Franklin LA, Osmond CB, Larkum AWD (2003) Photoinhibition, UV-B and algal photosynthesis. In: Larkum AW, Douglas SE, Raven JA (eds) Photosynthesis in Algae. Kluwer Academic Publishers, the Netherlands, pp 351-384

Grzymski J, Orrico C, Schofield OM (2001) Monochromatic ultraviolet light induced damage to Photosystem II efficiency and carbon fixation in the marine diatom
Thalassiosira pseudonana (3H). Photosynth Res 68: 181-192

Hanelt D (1996) Photoinhibition of photosynthesis in marine macroalgae. Sci Mar 60: 243-248

Hanelt D (1998) Capability of dynamic photoinhibition in Arctic macroalgae is related to their depth distribution. Mar Biol 131: 361-369

Hanelt D, Wiencke C, Nultsch W (1997) Influence of UV radiation on the photosynthesis of Arctic macroalgae in the field. J Photochem Photobiol B Biol 38: 40-47

Hanelt D, Wiencke C, Bischof K (2003) Photosynthesis in marine macroalgae. In: Larkum AW, Douglas SE, Raven JA (eds) Photosynthesis in Algae. Kluwer Academic Publishers, the Netherlands, pp 413-435

Henry BE, van Alstyne KL (2004) Effects of UV radiation on growth and phlorotannins in Fucus gardneri (Phaeophyceae) juveniles and embryos. J Phycol 40: 527-533

Huovinen PS, Oikari AOJ, Soimasuo MR, Cherr GN (2000) Impact of UV radiation on the early development of the giant kelp (Macrocystis pyrifera) gametophytes. Photochem Photobiol 72: 308-313

Karsten U, Sawall T, Hanelt D, Bischof K, Figueroa FL, Flores-Moya A, Wiencke C (1998) An inventory of UV absorbing mycosporine-like amino acids in macroalgae from polar to warm-temperate regions. Bot Mar 41: 443-453

Karsten U, Bischof K, Hanelt D, Tüg H, Wiencke C (1999) The effect of UV radiation on photosynthesis and UV-absorbing substances in the endemic Arctic macroalga Devaleraea ramentacea (Rhodophyta). Physiol Plant 105: 58-66

Lois R, Buchanan BBN (1994) Severe sensitivity to ultraviolet radiation in an Arabidopsis mutant deficient in flavonoid accumulation: II. Mechanisms in UV-resistance in Arabidopsis. Planta 194: 504-509

Lüder UH, Clayton MN (2002) Induction of phlorotannins in the brown macroalga Ecklonia radiata (Laminariales, Phaeophyta) in response to simulated herbivory - the first microscopic study. Planta 218: 928-937

Lüning K (1980) Critical levels of light and temperature regulating the gametogenesis of three Laminaria species (Phaeophyceae). J Phycol 16: 1-15

Michler T, Aquilera J, Hanelt D, Bischof K, Wiencke C (2002) Long term effects of ultraviolet radiation on growth and photosynthetic performance of polar and cold-temperate macroalgae. Mar Biol 140: 1117-1127

Murphy TM (1983) Membranes as targets of ultraviolet radiation. Physiol Plant 58: 381-388

Pakker H, Beekan CAC, Breeman AM (2000) Efficient photoreactivation of UVBR-induced DNA damage in the sublittoral macroalga Rhodymenia pseudopalmata (Rhodophyta). Eur J Phycol 35: 109-114 
Pavia H, Brock E (2000) Extrinsic factors influencing phlorotannin production in the brown alga Ascophyllum nodosum. Mar Ecol Prog Ser 193: 285-294

Pavia H, Cervin G, Lindgren A, Åberg P (1997) Effects of UV-B radiation and simulated herbivory on phlorotannins in the brown alga Ascophyllum nodosum. Mar Ecol Prog Ser 157: 139-146

van de Poll WH, Eggert A, Buma AGJ, Breeman AM (2001) Effects of UV-B-induced DNA damage and photoinhibition of growth of temperate marine red macrophytes: habitatrelated differences in UV-B tolerance. J Phycol 37: 30-37 van de Poll WH, Hanelt D, Hoyer K, Buma AGJ, Breeman AM (2002) Ultraviolet-B-induced cyclobutane-pyrimidine dimmer formation and repair in Arctic marine macrophytes. Photochem Photobiol 76: 493-501

Ragan MA, Glombitza KW (1986) Phlorotannins, brown algal polyphenols. In: Round FE, Chapman DJ (eds) Progress in Phycological Research 4. Biopress Ltd, Bristol, UK, pp 129-241

Roleda MY, van de Poll WH, Hanelt D, Wiencke C (2004) PAR and UVBR effects on photosynthesis, viability, growth and DNA in different life stages of two coexisting Gigartinales: implications for recruitment and zonation pattern. Mar Ecol Prog Ser 281: 37-50

Roleda MY, Wiencke C, Hanelt D, van de Poll WH, Gruber A (2005) Sensitivity of Laminariales zoospores from Helgoland (North Sea) to ultraviolet and photosynthetically active radiation: implications for depth distribution and seasonal reproduction. Plant Cell Environ 28: 466-479

Roleda MY, Clayton MN, Wiencke C (2006a) Screening capacity of UV-absorbing compounds in spores of Arctic Laminariales. J Exp Mar Biol Ecol 338: 123-133

Roleda MY, Hanelt D, Wiencke C (2006b) Exposure to ultraviolet radiation delays photosynthetic recovery in Arctic kelp zoospores. Photosynth Res 88: 311-322

Roleda MY, Wiencke C, Lüder UH (2006c) Impact of ultraviolet radiation on cell structure, UV-absorbing compounds, photosynthesis, DNA damage, and germination in zoospores of Arctic Saccorhiza dermatodea. J Exp Bot 57: 3847-3856

Schoenwaelder MEA (2002) The occurrence and cellular significance of physodes in brown algae. Phycologia 41: 125-139
Schoenwaelder MEA, Clayton MN (1998) The secretion of polyphenolic compounds following fertilization in Acrocarpia paniculata (Fucales, Phaeophyceae). Phycologia 37: 40-46

Schoenwaelder MEA, Clayton MN (1999) The presence of phenolic compounds in isolated cell walls of brown algae. Phycologia 38: 161-166

Setlow RB (1974) The wavelengths in sunlight effective in producing skin cancer: a theoretical analysis. Proc Natl Acad Sci USA 71: 3363-3366

Svendsen P (1959) The algal vegetation of Spitsbergen. A survey of the marine algal flora of the outer part of Isfjorden. Norsk Polarinstitutt Skrifter 116: 1-49

Swanson AK, Druehl LD (2002) Induction, exudation and the UV protective role of kelp phlorotannins. Aquat Bot 73: 241-253

Vass I (1997) Adverse effects of UV-B light on the structure and function of the photosynthetic apparatus. In: Pessarakli M (ed) Handbook of Photosynthesis. Marcel Dekker Inc., New York, pp 931-949

Véliz K, Edding M, Tala F, Gómez I (2006) Effects of ultraviolet radiation on different life cycle stages of the Pacific kelps, Lessonia nigrescens and Lessonia trabeculata (Laminariales, Phaeophyceae). Mar Biol 149: 1015-1024

Wiencke C, Gómez I, Pakker H, Flores-Moya A, Altamirano M, Hanelt D, Bischof K, Figueroa FL (2000) Impact of UV radiation on viability, photosynthetic characteristics and DNA of brown algal zoospores: implications for depth zonation. Mar Ecol Prog Ser 197: 217-229

Wiencke C, Clayton MN, Schoenwaelder M (2004a) Sensitivity and acclimation to UV radiation of zoospores from five species of Laminariales from the Arctic. Mar Biol 145: $31-39$

Wiencke C, Vögele B, Kovaltchouk NA, Hop H (2004b) Species composition and zonation of marine benthic macroalgae at Hansneset in Kongsfjorden, Svalbard. Ber Polarforsch Meeresforsch 492: 55-62

Wiencke C, Roleda MY, Gruber A, Clayton MN, Bischof K (2006) Susceptibility of zoospores to UV radiation determines upper depth distribution limit of Arctic kelps: evidence through field experiments. J Ecol 94: 455-463 